SH 473

.H7

Copy 2 
307

and and

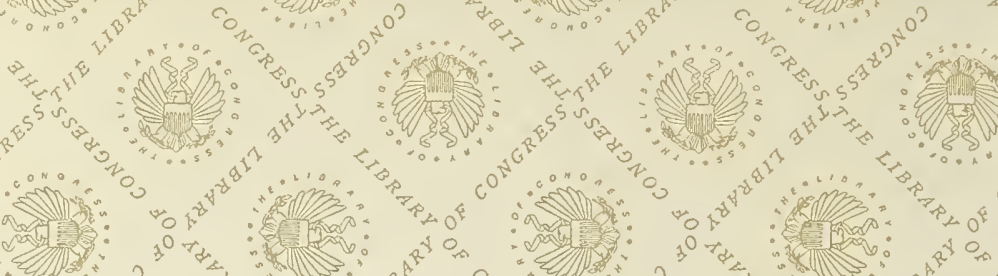

$3^{0} \%$

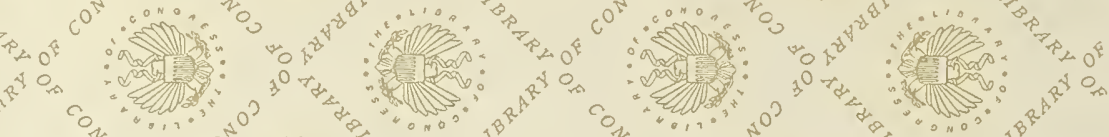

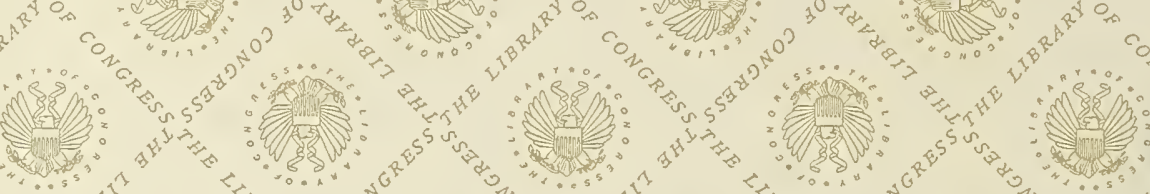

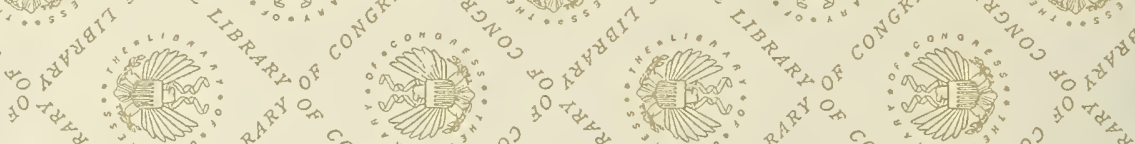

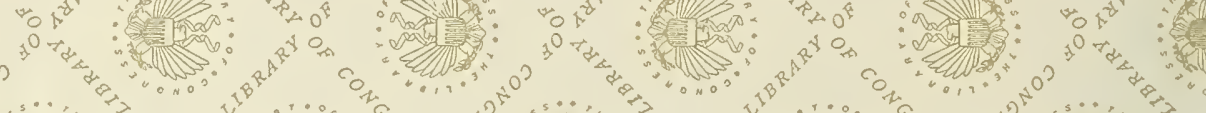
$4=$ N

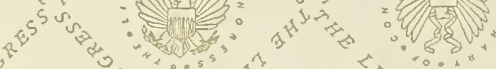

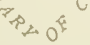
${ }^{2} 0^{0}$ a

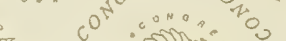
(1)

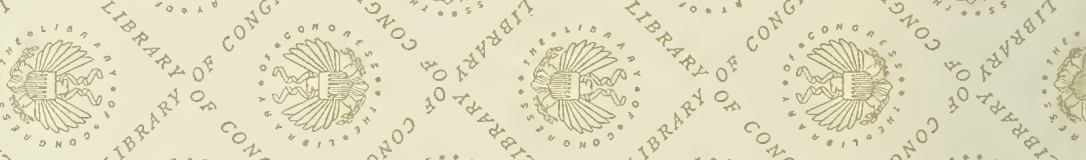
Lind $P_{20}$

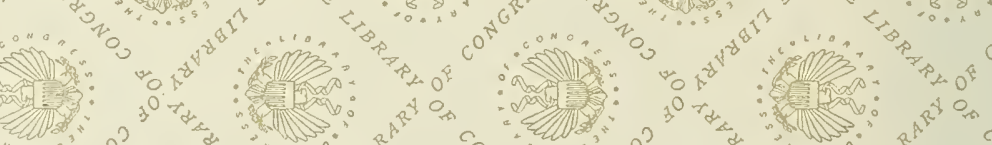
Nis. (a)

nou

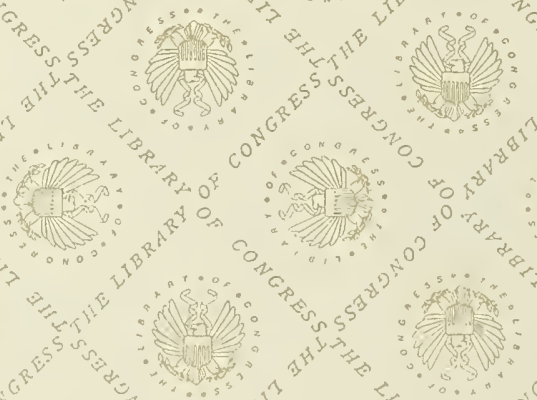




\section{$-\infty a y$

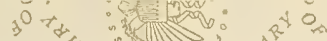 \\ $x_{0}-\gamma^{2}$ \\ chim \\ - ins}

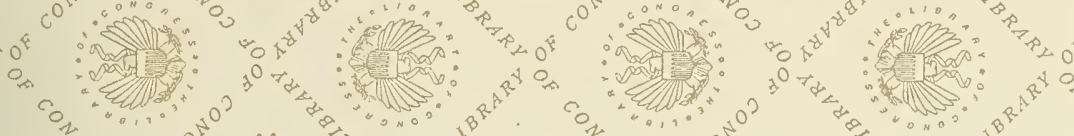

a):

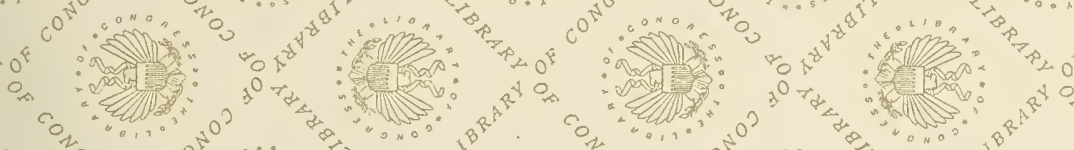

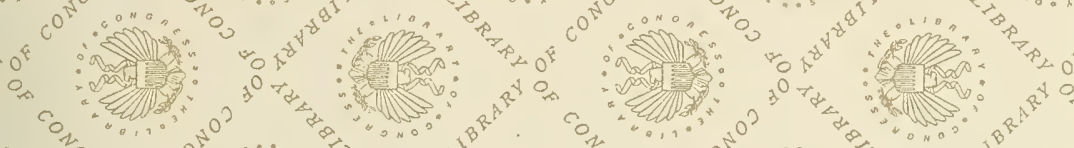

a):

की की की

El 3

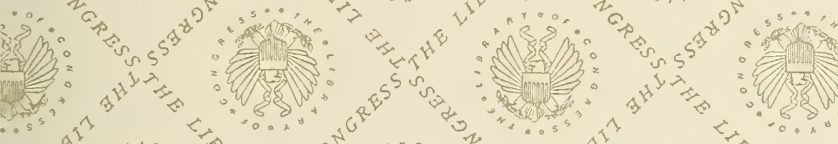

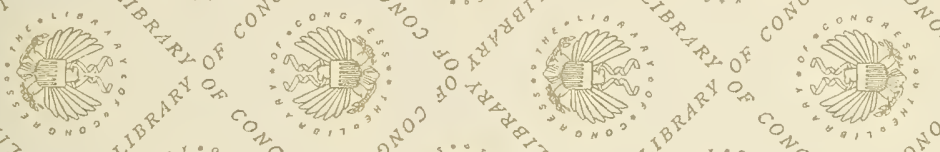

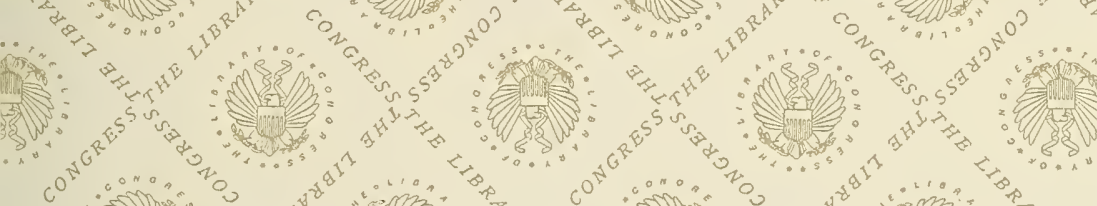

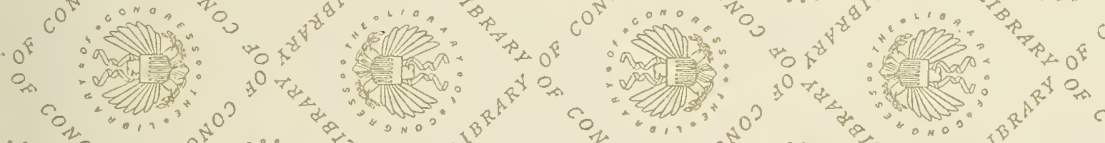

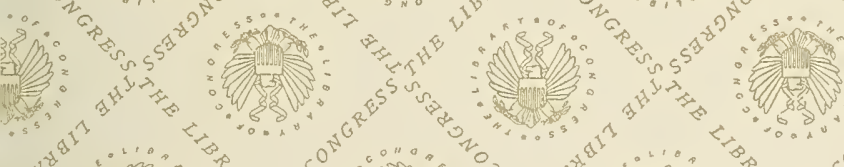

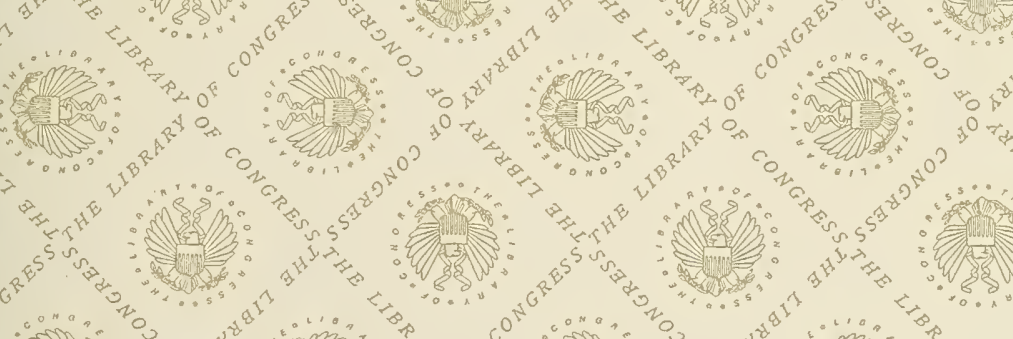

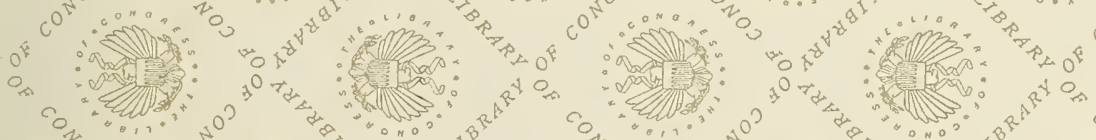



, 



\section{SPORT FISHING IN CALIFORNIA AND FLORIDA}

From BULLETIN OF THE BUREAU OF FISHERIES, Volume XXVIII, I908

Procedings of the Fourth International Fishery Congress : : Washington, Ioo8

\footnotetext{
Prington,
}

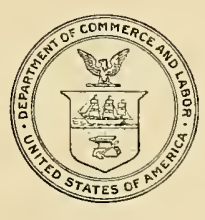

Holder

WASHINGTON : $:: \quad: \quad:$ GOVERNIINT PRINTING OFFICE $: \quad: \quad: \quad: \quad: 1910$ 


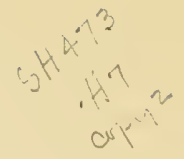

BUREAU OF FISHERIES DOCUMENT NO. 652

Issued February, 1910

MAR I 1910

$90 \%$ 


\title{
SPORT FISHING IN CALIFORNIA AND FLORIDA
}

\section{$*$}

\author{
By Charles F. Holder
}

*

Paper presented before the Fourth International Fishery Congress

held at Washington, U. S. A., September 22 to 26, 1908 



\title{
SPORT FISHING IN CALIFORNIA AND FLORIDA.
}

\author{
$*$ \\ By CHARLES F. HOLDER.
}

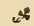

It is not generally appreciated by the public that "sport" has economic value. By the unthinking it is not taken into account in the evolution of a country, being considered a waste of time, a mere amusement. Yet sport brings four or five million dollars into the state of Maine every year, and sport, particulariy angling, brings quite as large a sum annually to California.

Over I 70,000 people visit the Channel Islands of California every year. They make the attractive pilgrimage mainly to the shrine of Walton, for here, from Coronado to Santa Barbara and particularly at Santa Catalina and San Clemente (a United States Government island), is to be found the finest sea angling in the world.

Rod and reel fishing has been reduced to an exact science here, and this has been accomplished through the Tuna Club, an organization which includes in its membership most of the notable sportsmen of the country-as Ex-President Roosevelt, Henry Van Dyke, Gifford Pinchot, Charles Halleck, Casper Whitney, the late Ex-President Grover Cleveland, and many more. This club has introduced light-tackle fishing as a sportsmanlike movement, also to prevent the undue slaughter of fish, and thus accomplishes a most valuable work in conserving all the resources of the ocean. By this club's efforts business in fishing tackle has been enhanced a thousand times; hundreds of people find direct employment as boatsmen and employees in allied interests; large sums are brought into the state from numerous parts of this country and Europe and sport, or one feature of it, has been elevated and dignified as a state and national asset of unquestionable importance. In the present paper some of the most important of the great game fishes of southern California and Florida are described.

\section{AT SANTA CATALINA ISLAND.}

The black sea bass of Santa Catalina is a game and food fish which attains a weight of 800 pounds, averaging 250 pounds, and is very common in this locality, living in and about the kelp or nereocystean forests that surround the island. It appears in May in schools of six or seven, breaks up and is ready to 
spawn in August. Professional fishermen take it for the market with "cod" lines and albacore bait, but the anglers of the Tuna Club use 24-ounce and 9-ounce rods with a reel that will hold $\mathrm{I}, \mathrm{OoO}$ feet of a 9-thread Cuttyhunk line made for the purpose. The line is made in a building 700 feet long and is tested to pull a dead weight of 2 pounds to the thread. With this tackle the anglers go to the grounds in launches especially designed for the purpose, 18 or 20 feet long with 8 or ro horsepower gasoline engines. In the stern are two comfortable chair seats, one fishing to the right, the other to the left. On reaching the ground the boatman tosses over the anchor, fixing a float to it that he can cast off. The angler straps on a belt with a socket for the butt of his rod, baits the number 7/o O'Shaughnessy hook with half a barracuda, or a 6-pound whitefish, or a piece of albacore, and tosses it over in 40 feet of water. He may have to wait for a strike or he may get one immediately. The strike is delicate, and when it comes the angler pays out ro or 20 feet of line, then strikes. If he hooks the fish there is a heavy rush and the boatman casts off the anchor (fig. 1, pl. r) and follows the fish, or keeps the angler stern to it until he brings it to gaff, which may take an hour or five, according to the fish. The gaffer, if the fish is large, tows it in, if small (I 50 pounds), he takes it on deck (fig. 2, pl. I) and goes into port (fig. 3, pl. II), where scores of people hurry down to the dock to see the fish weighed.

The tuna of the Pacific, or horse mackerel, or tunny, is taken in the Mediterranean in great nets, miles long, being driven in, and the nets at Sicily are of great value. In America the tuna, of three kinds, is taken as sport and is also used as a food fish. The leaping tuna comes into Catalina in June and remains until January. It is considered the greatest of all game fishes. The tackle is a 2 -ounce rod, a 24 -thread Cuttyhunk or other good line, and a large reel of Vom Hofe make. The angler does not wear a belt, but has a socket on the seat for the butt of the rod. (Fig. 5, pl. IIr.) Flying fish is the bait, which is trolled about 100 feet behind the boat. Anglers play the fish and troll for it. They also approach the schools and cast the heavy bait in front of them. The fish average 170 pounds (fig. $6, \mathrm{pl}$. III) and the record is $25 \mathrm{I}$ pounds with the tackle described. Market fishermen fish with heavy lines from sail boats, but the fish is so powerful that few care to do it. The fish is a famous leaper before it is hooked and when feeding, and preys almost exclusively on flying fish and squid. It is found in all temperate and semitropic seas, and often weighs I,500 pounds. This tuna is fished for a quarter of a mile offshore on about 4 miles of coast at Santa Catalina and has not been taken with a rod in any other locality. It has been known to tow a boat for 30 miles.

The albacore, long-finned tuna, or alalonga, ranges up to roo pounds and is found in many localities off Santa Catalina Island. It lives in deep water but near the surface. It looks something like the blue tuna but has very long 
pectoral fins. It is followed by anglers and taken with either a 6-ounce rod with 6 or 3 thread line (this for experts) or a 9-ounce rod with 9-thread line. The bait is sardine and the fish are so ravenous that they will at times snatch a sardine from one's hand, or the game can be hooked at the side of the boat when the school is located, during which operation the bait is towed behind the boat.

The yellow-finned tuna, which is a beautiful fish and attains a weight of Ioo pounds, averaging 45, is common in Japan and at Honolulu, and appears at Santa Catalina in September. The largest specimens are taken with rod and reel for market and sport. It resembles the leaping tuna but has a short fin, with the finlets a vivid lemon-yellow. (Fig. I , pl. vr.) It will tow a boat 2 or 3 miles.

The bonito or skip jack is another of the beautiful fishes of California and other seas. It is taken with a 6-ounce rod, no. 6 line, small hook (7/o), and sardine bait. The hook in baiting is thrust through the mouth, out and into the side, the mouth of the fish closed by being wound by wire. The bonito attains a weight of 20 pounds and is a vigorous fighter, having a peculiar wriggling motion, and playing on the surface entirely. The angler follows it in launches.

The oceanic bonito comes in early spring. It attains a weight of 25 pounds, is beautifully barred and silvery. It is taken on a 6-ounce rod, and a line that will stand a dead strain of 12 pounds; sardine bait, a long piano wire leader, 6/o hook and light sinker. (Fig. 4, pl. Ir.) The boat proceeds at a rate of 3 or 4 miles an hour trolling 80 feet of line, and the fish is gaffed when brought in.

The white sea bass is a food and game fish of California attaining a weight of roo pounds. It is taken by market men in nets at Monterey, but at Catalina is a great game fish (fig. 7), and to encourage anglers to use light rods valuable prizes are offered for the big specimens. The club record is 60 pounds. The fish is taken with a 9-ounce rod, 9-thread line, by trolling with a sardine on a 7/o hook and 6-foot piano wire leader. It makes a fine play, and requires skill to land. The white sea bass appears in May and disappears in August, and except in Monterey may be considered an offshore fish, being taken in greatest numbers at the Channel Islands of California. In the Gulf of California it attains a weight of ${ }^{5} 5^{\circ}$ pounds, and is often taken in the surf on the east coast of the Gulf, north of Tiburon. It prefers flying-fish bait, but live smelt or sardine is good; also a Wilson spoon in trolling. The live bait is used in stillfishing, the plan being to drop an empty hook into a school of sardines and snag a fish, which, if there is a white sea bass around, will be taken at once. Remarkable catches are made in Avalon Bay, where the fish all weigh over 50 pounds. There is another species of the fish, averaging 15 pounds, called "sea trout," which is taken in the same way. Both species are related to the eastern weakfish, or squeteague. 
The yellowtail of the Pacific coast is not the yellowtail of Florida, but is closely related to the amberfish, or amber jack, of the latter region. It is the common fish of southern California, where it attains weight of 100 pounds. The rod record is 60 pounds. It is a beautiful fish, blue, silver, with yellow median line fins and finlets, and all in all the hardest fighting fish known. It is taken by hand lines for the market in deep water near shore or at the surface. In the early season it runs in schools, but breaks up and solitary fish are often seen. If the winter in southern California is warm and dry, the yellowtail is taken every month in the year, but if cold the fish goes to offshore banks or down into very deep water, where its food supply also doubtless winters. It is taken from rowboats (fig. 8 , pl. Iv) or launches, with rods 6 or 9 ounce split bamboo, 6 feet or over in length; medium-sized reel, 9-thread line, with 6 -foot leader of wire, $7 / 0$ hook, and large flying-fish or small sardine bait (large fish take the former). It can be taken by still fishing or trolling, is a wharf fish as well, and is also taken under kelp patches miles out to sea. It is the fish of the people in California, worth thousands to the state as a game fish (fig. I I, pl. vi), and equally valuable as a food supply to the masses. It spawns in the summer.

The barracuda, found in schools in California in summer, is taken in gill nets, also on light tackle rods. It is a good food but poor game fish. In August the schools break up and individual fish are seen. The barracuda takes sardine or smelt bait.

The ocean sunfish (fig. 9, pl. v) taken for sport, attains a weight of 2,200 pounds in California, and is found all over the world in temperate waters. It takes bait but rarely. The author hooked one August 26, 1908, and landed it by rushing at it in a launch, gaffing it quickly, and holding on to it, despite its rushes. It weighed half a ton doubtless, and was ro feet high. This fish is very common in southern California waters. On pleasant days it can be seen jumping, and the pursuit of it constitutes sport for those who like lusty pastimes at sea. It is generally taken with a spear, but to hook it and rush the launch in and gaff it before it goes down is a game that has no little excitement. I have taken large specimens off the Atlantic coast in this way and once off the Florida coast. No more extraordinary creature can be imagined than this colossus with no appreciable tail, a fish all head with its two huge fins pointing up and down, dotted with waving parasites, splashed and spotted with membranifera, sailing along in the deep blue sea. The small ones go in schools. The skin is used as sandpaper, the muscle as rubber for balls.

The California flying fish is taken as food in seven ways: One by setting a gill net at the surface; the fish is so stupid that the moment it touches the net it stops and turns over and is easily caught. The sportsmanlike way to take it is to shoot it with a shotgun. This I have accomplished by seating myself 
in the bow of a fast launch, and as the flying fish rises on either hand shooting it either to the right or left. A good dog might be trained to spring and retrieve flying fish, though the ordinary plan is to run alongside and take them with a scoop net. The fish are in demand as food but are more valuable as bait for tuna or yellow-tail fishing, bringing $\$ 1$ a dozen in the season from May to October. Numbers of people have been struck by them. One hit the writer in the neck and nearly knocked him overboard. The fish does not fly but soars, holding its wings rigid and covering a distance of a quarter of a mile.

At Santa Catalina the sheepshead is a good game fish. It is taken either from the rocks or from the boats near shore. The tackle used is an 8 or 9 ounce rod, a 6-thread line, and abalone or crayfish bait. A sinker should be used, as the fish is found on or near the bottom.

A good hard-fighting fish caught here is the leaping shark, taken from the beach of Catalina Harbor with a light rod. Like the tarpon, the fish will leap as soon as hooked, and for a while makes a very fair fight.

\section{SALMON AND TROUT IN CALIFORNIA.}

One of the finest game fishes in America is the salmon, taken with rod and reel in the streams and rivers of Canada. On the Pacific coast the salmon congregate in Monterey Bay before entering the rivers. At Monterey, Santa Cruz, and Capitola they are fished for from boats, the professional fishermen with big boats, using hand lines and heavy sinkers, in water 40 or 50 feet deep, with sardine bait, but the sportsmen using a rod weighing 9 ounces, with a 9-thread line and 7/o hook baited with smelt, anchovy, or sardine. A sinker is needed, and an ingenious device is used to release the sinker and enable the man to play the fish. The line near the hook is connected by a thread on which is run a pipe sinker of lead. When the fish strikes the thread breaks, releasing the line, and the angler plays the salmon, which comes to the surface and leaps, making a fine play. Large catches are made (fig. Io, pl. v).

California abounds in trout, and the methods of angling are the same as in the East, 2, 3, 4, 6, and 8 ounce split bamboos being the rods most in vogue, with "E" silk lines and 6-foot leaders and one fly, of a kind depending upon the locality. At Klamath Lake, where the giant rainbows are found, the "March Brown" fly is the best, the fish making a fine play, leaping from the water. In Feather River, Plumas County, Cal., they are taken in the same way. The river is swift, and the fly fishing excellent, big deep pools being found everywhere here. A cork fly or "grasshopper" is very killing.

In the Sacramento, also in the Kern and other streams, the fishing is excellent with the fly. The black bass has been introduced, also the striped bass in the waters about San Francisco Bay. 


\section{ON FLORIDA COASTS.}

Florida is famous for its game fishes, and, except the tarpon, they are also food fishes. The tarpon is the great game fish of the world. In some localities it is taken with hand lines, but the method in vogue among sportsmen is to take it with a 9 -ounce rod, 9 -thread line, and 1o/o hook with mullet bait. The boat (launch or rowboat) trolls slowly, with 30 or 40 feet of line out, and at the strike the fish goes into the air in repeated leaps, giving a fine play. One hundred miles south of Galveston, on the Gulf, is the Aransas Pass Tarpon Club, a well-known organization, and when brought to the boat here the fish is towed inshore, measured, and released. Here, as in Florida as well, in shallow water, the big jewfish also is taken, with I6-ounce rods, 24 -thread line, large hook, and wire leader. This fish attains a weight of 400 or 500 pounds, is sluggish, and found in holes.

One of the interesting food and game fishes is the hogfish, beautiful in rich red tints and with waving plume-like fins. A hand line is used for its capture, the sinker on the bottom and large hook 2 feet above, so that it will swing clear of the coral. This is lowered in water from 30 to 60 feet deep in the coral, and catches of 5 pounds are taken.

In shallow waters the most beautiful of all the Florida fishes is the gray snapper. It is caught by the professionals with hand lines, as above, with crawfish or conch bait; but an 8-ounce bass rod is to the sportsman's taste, with a fine no. 6 line, and a bunch of small sardines for bait. The fish resembles a black bass, and plays like one, but does not jump. There are a number of snappers, all caught the same way.

Related to the snappers is the beautiful little yellowtail, with yellow stripes and fins. A 6-ounce rod, a no. 6 line, and 4-inch hook baited with crawfish is the lure, and on the shallow reef among the gorgonians or sea fans it is found in great numbers, affording good sport, besides being an excellent pan fish. This fish is quite different from the big yellowtail of the California coast.

Along the mainland is found the sea trout or squeteague, a fine game fish, taken with the same tackle. No fish makes a better fight. The bait for it may be sardine, smelt, or crab.

Common wharf fishes of Florida are the porgies, which throng some localities in myriads. They are good pan fish.

Notable food fishes here are the groupers. The red grouper is the most valuable, and specimens weighing 50 pounds have been taken. It is a deepwater fish, caught on a hand line, with conch bait or anything at hand. Other groupers are taken on the same tackle (hook above the sinker).

The ladyfish is a splendid game fish, ranging up to 6 and 7 pounds, long, slender, and silvery. A 6 or 8 ounce rod, 6-thread line, crab or fish bait is the 
tackle. Upon being hooked the fish leaps into the air and literally dances over the water on its tail. The bonyfish is very similar in its action.

The common pan fish on the reef is the grunt, found literally in thousands. It is rather a poor game fish, but makes a fairly good play on a 6-ounce trout rod. Any bait is acceptable to the grunt, but especially crayfish. As its name suggests, it grunts when taken out of the water.

On the reefs are number of fishes known as " jacks," ranging up to 16 pounds and over. They run in schools and chase sardines, and can be caught with this bait. Few fish make a more game play, dashing through the water and breaking the line of the novice. They are mostly caught on the hand line trolling, but the true way to take them is with a 6 -ounce rod, 6 feet long, 6 line, $7 / 0$ hook, and sardine bait. This tackle is small and delicate for the fish, but can take them in the hands of a skillful angler.

At Palm Beach, the amberfish is taken with a Io-ounce rod, $2 \mathrm{I}$-thread line, and sardine bait. Boats are rowed out beyond the surf and still fishing is the method. This fish is allied to the California yellowtail, and puts up a splendid fight. The angler wears a belt with a leather socket in which he secures a certain leverage, and often plays the fish an hour or more before he brings it to gaff. (Fig. I2, pl. vi.) Amber jacks of 50 or 60 pounds are taken in this way.

The northern bluefish is a splendid catch on a 9-ounce rod, 9-thread line. So are the channel bass, drumfish, and striped bass. All should be taken with this tackle 



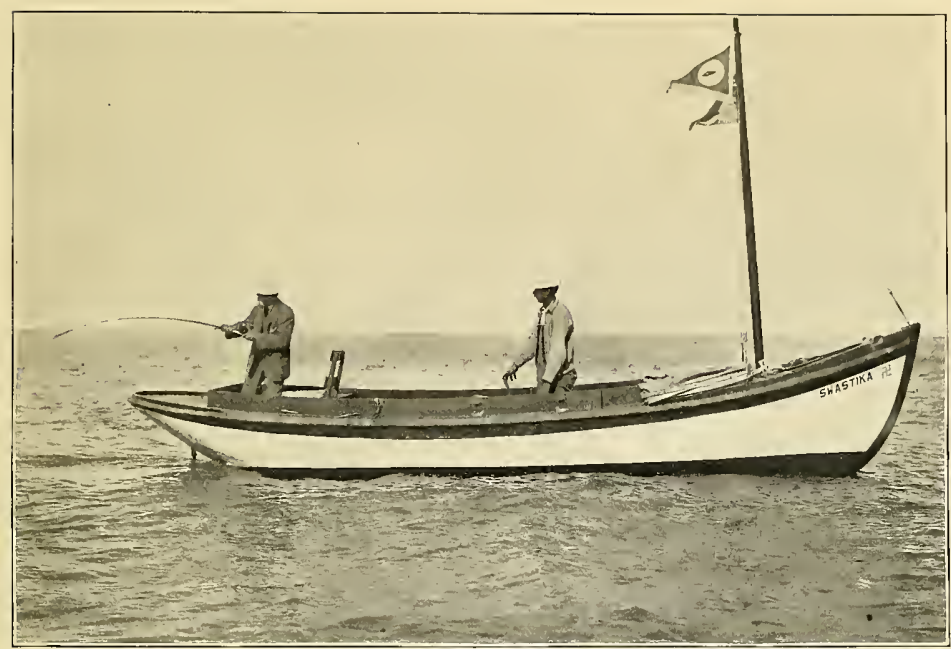

FIG. I. The strike

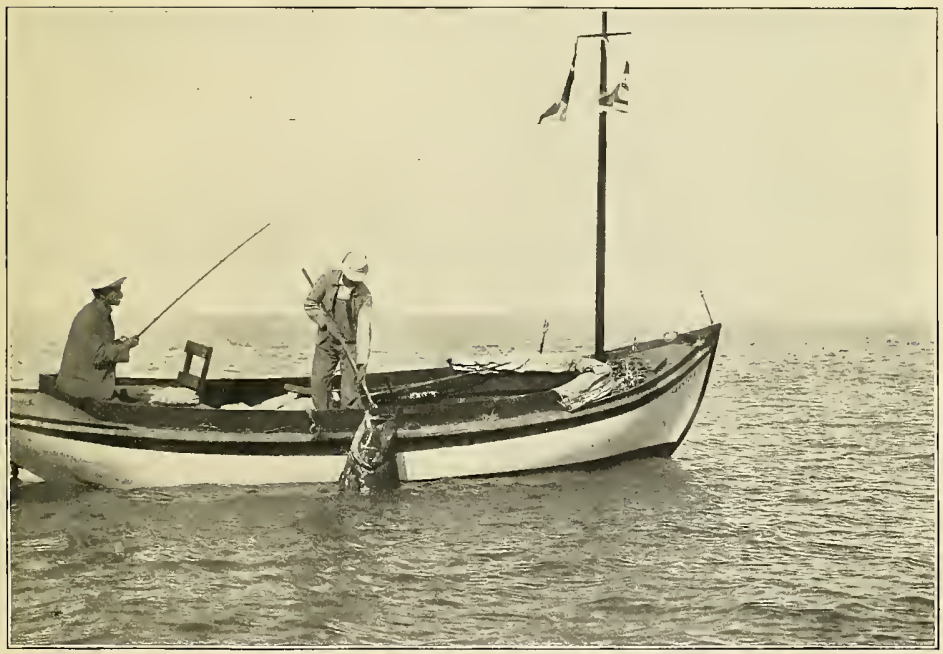

FIG. 2.-Gaffing a 240-pound capture.

ANGLING FOR BLACK SEA BASS, SANTA CATALINA ISIAND, 


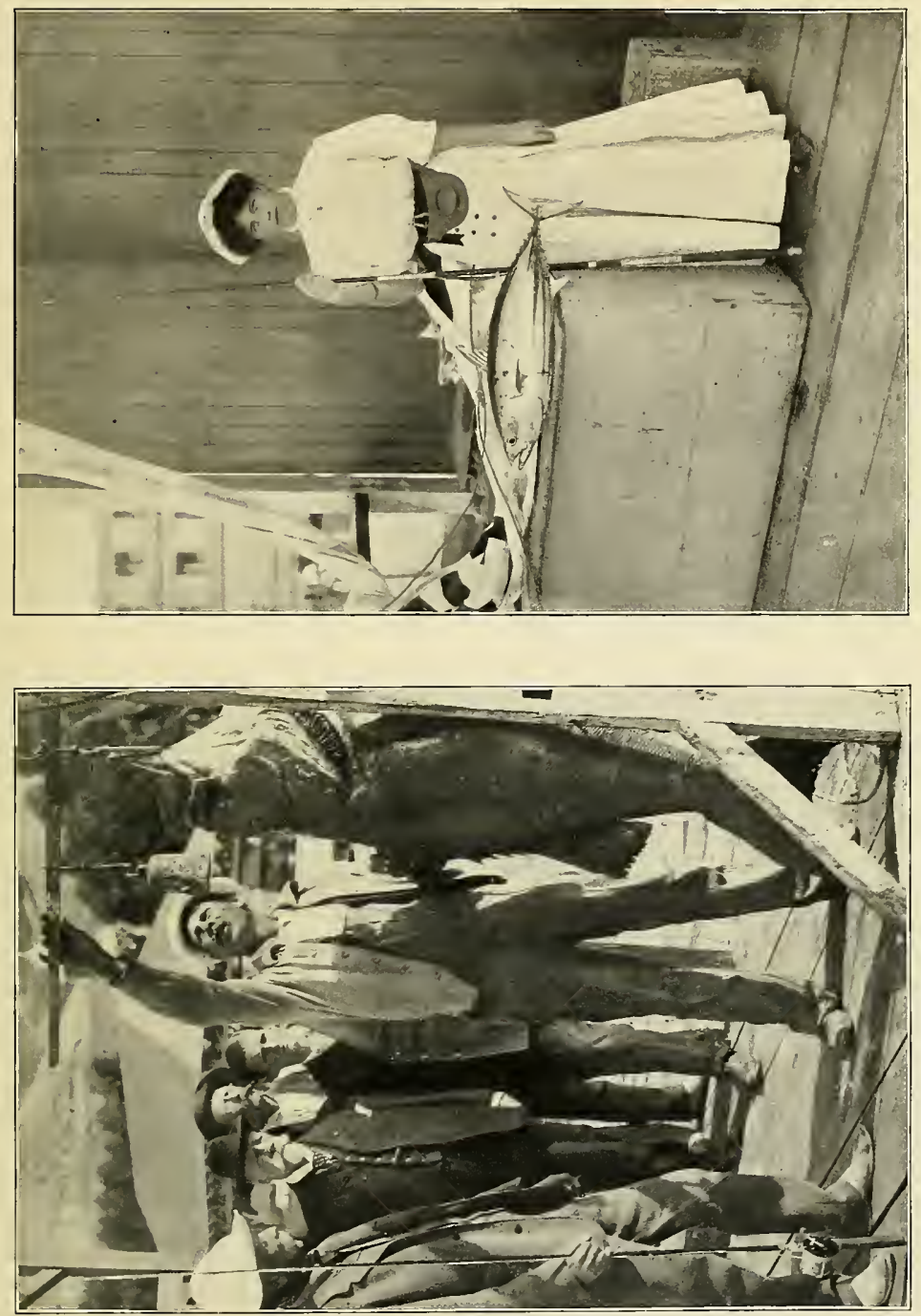


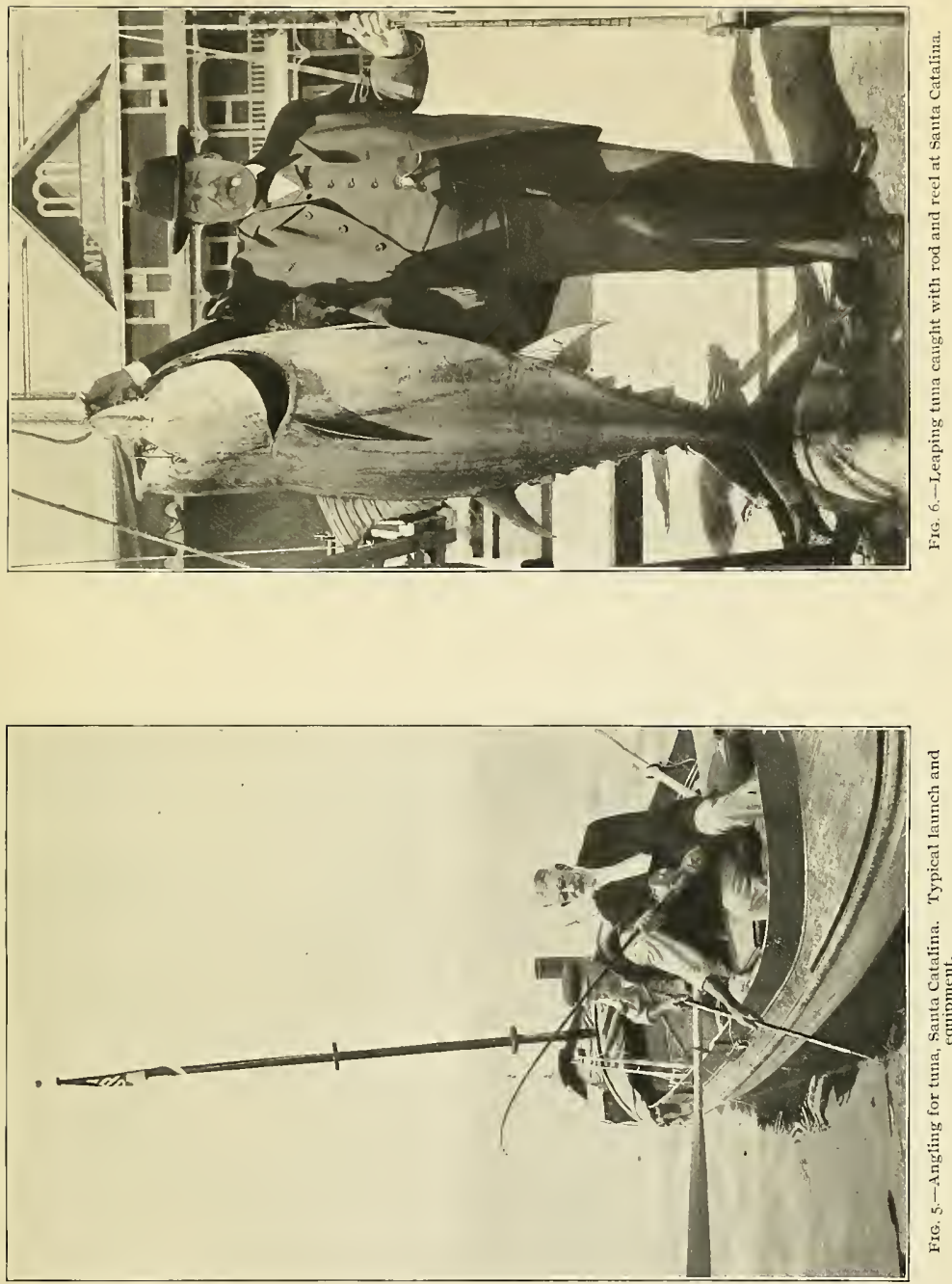



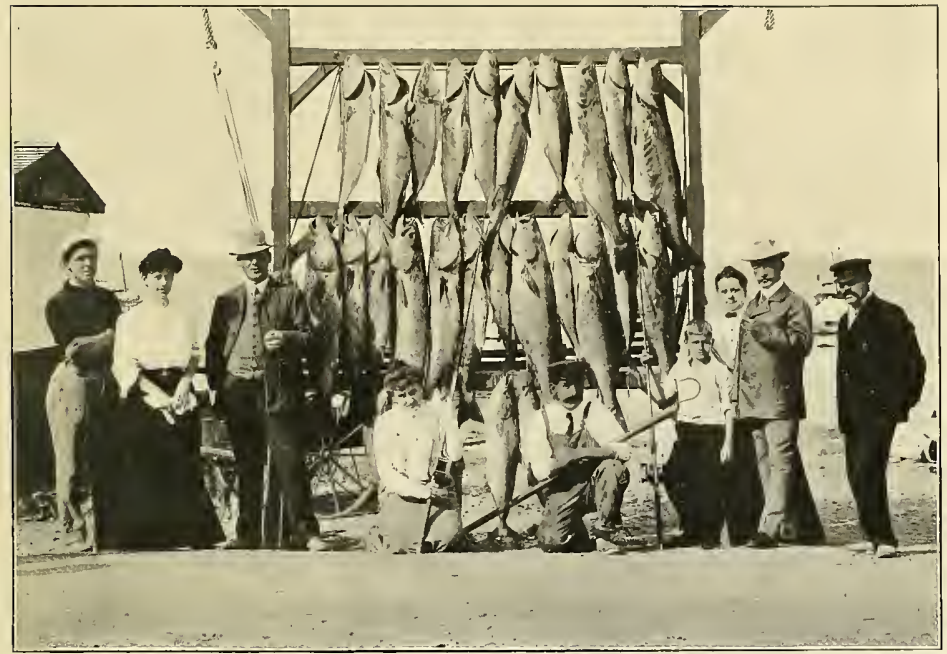

FIG. 7.-A day's sport at Santa Catalina Island with white sea bass.

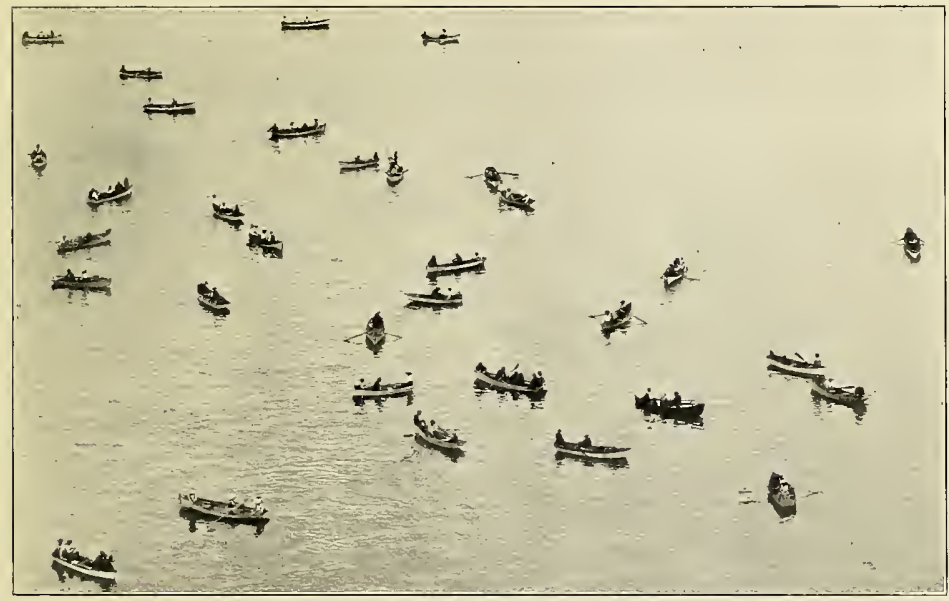

FrG. 8.-The yellowtail anglers of Avalon Bay, California (Santa Catalina Island); 200 to 300 boats often seen, all fishing with rod and reel. 

Bul, U. S. B. F., I 908.

PIATE $V$.

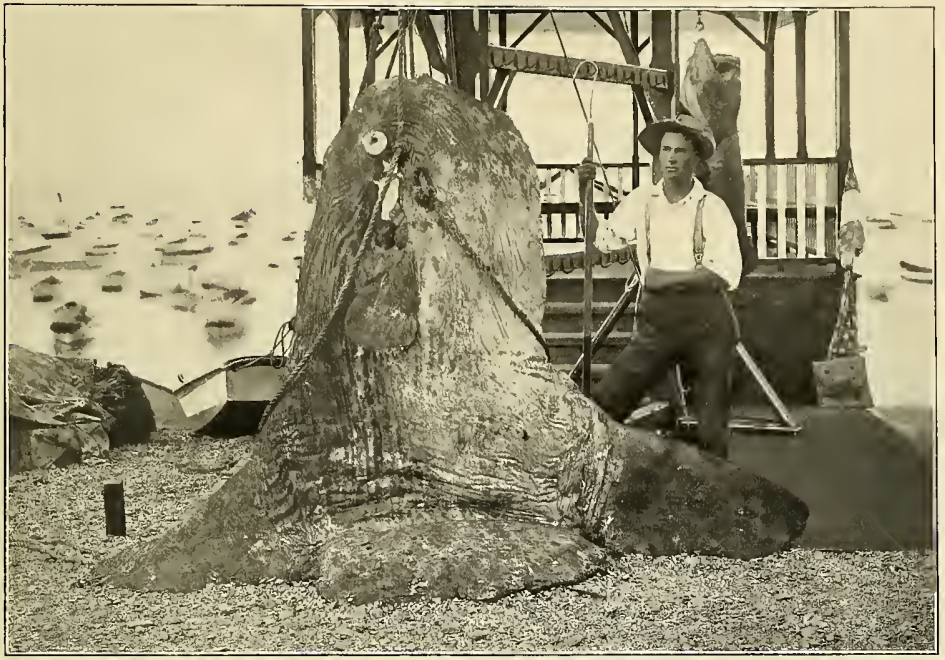

FIG. 9.-The record sunfish, Santa Catalina Island, too heavy to weigh; estimated at 2,500 pounds.

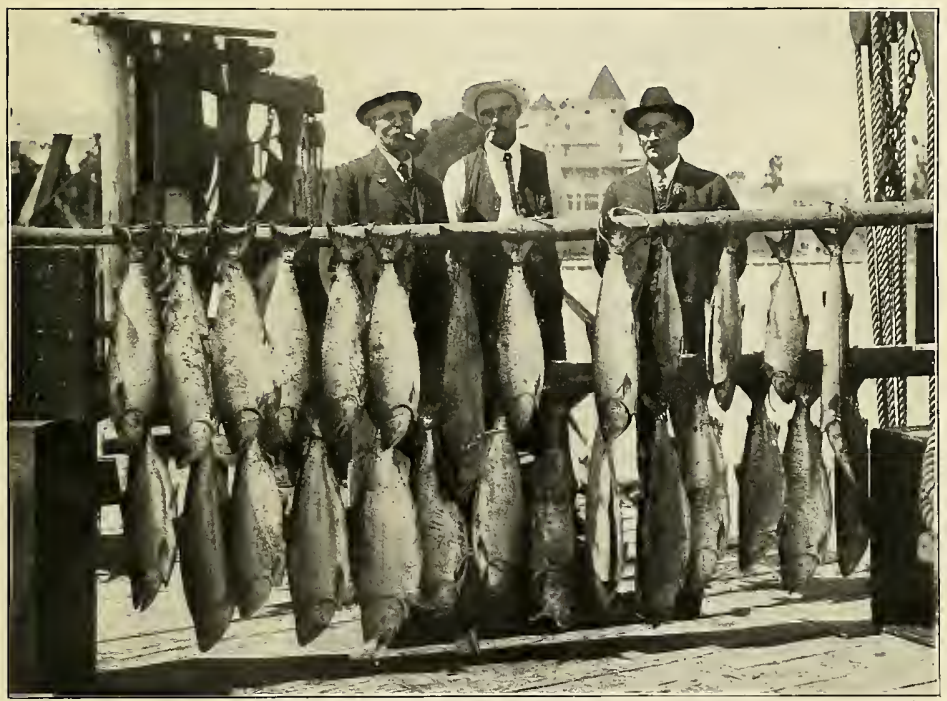

Fis, ro.-A salmon (rod and reel) catch, Del Mronte, California. 


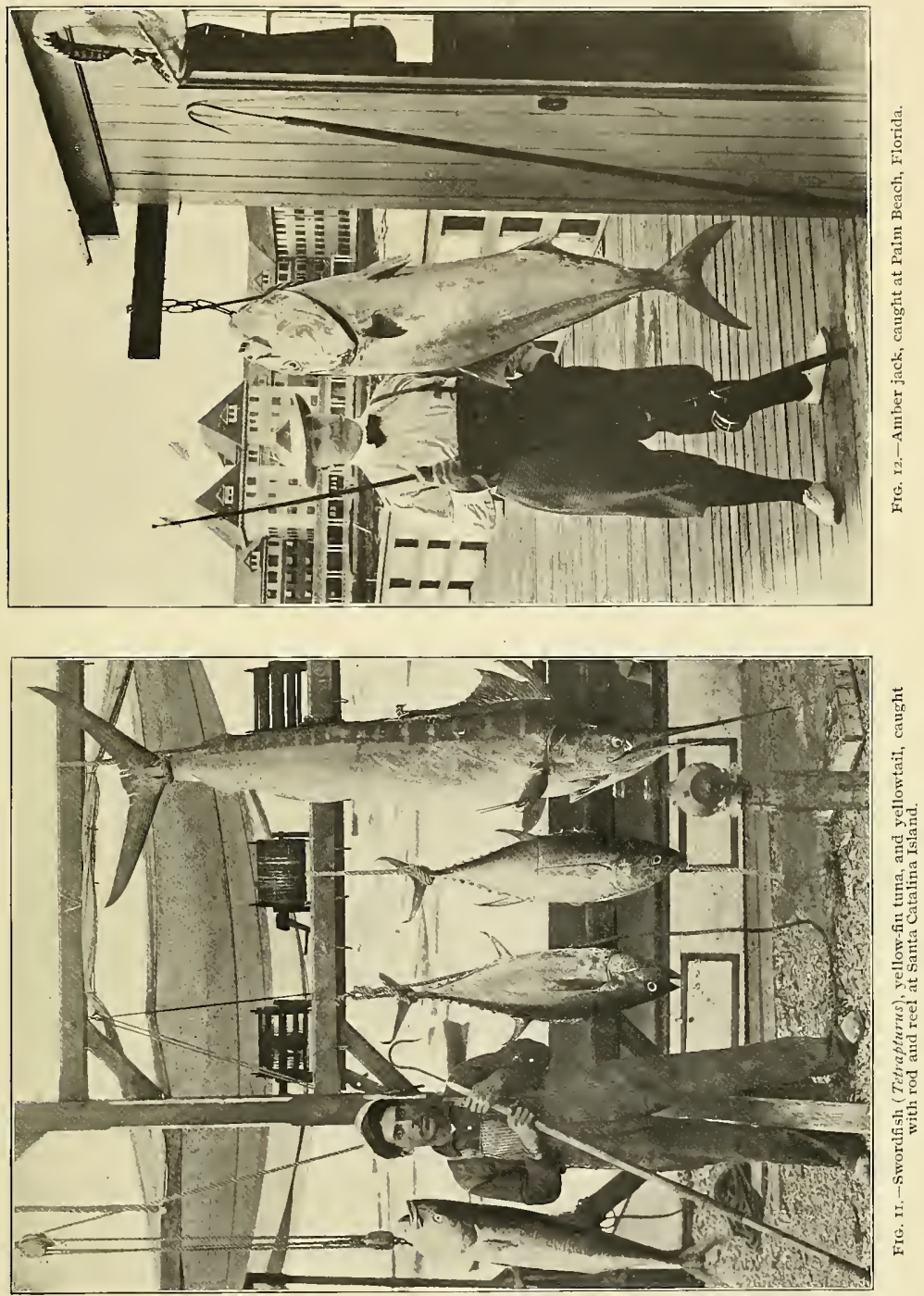
$\begin{array}{lll}H 132 & 78 \quad 567\end{array}$ 





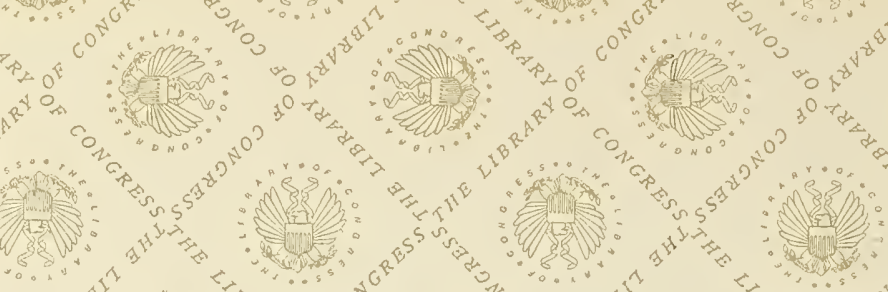

$$
\begin{aligned}
& \text { a } \\
& (-5)=(1) \\
& \text { ond ond }
\end{aligned}
$$

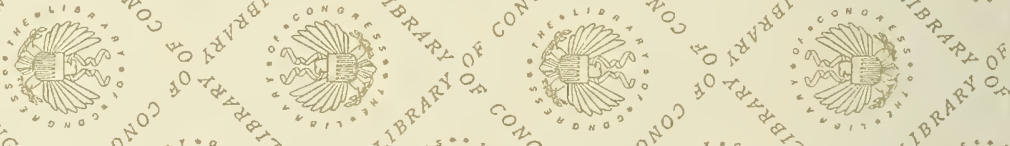
the

$$
\text { a }
$$

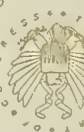

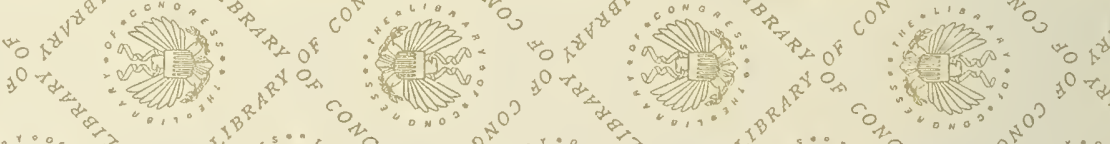

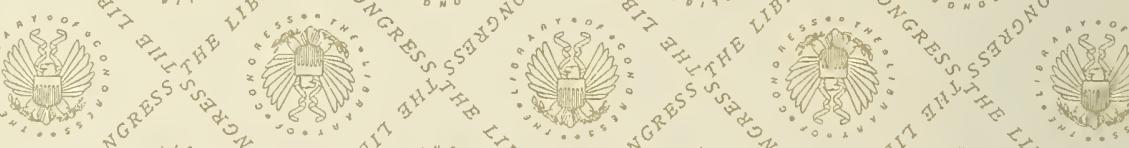

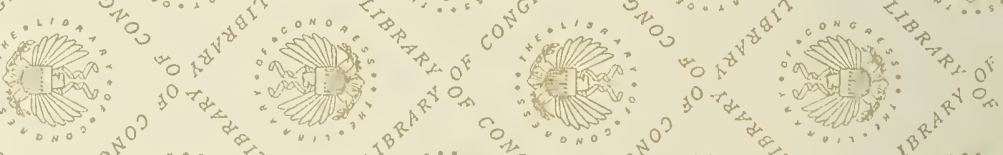
(1)

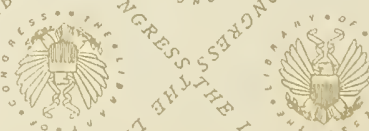




\section{-}

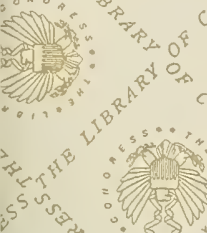

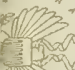

\section{:}

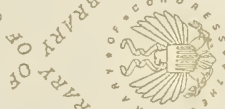

trintent

at en:

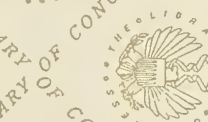

tent

1.

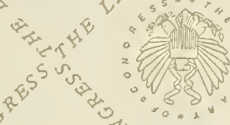

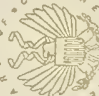

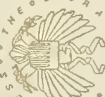

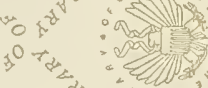

-

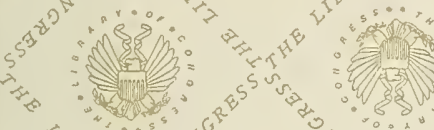

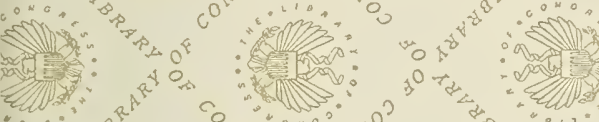

intsis

and

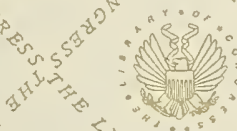

(1)

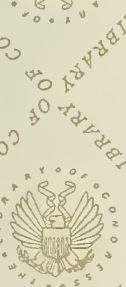

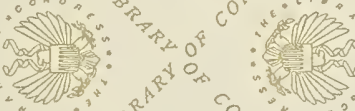

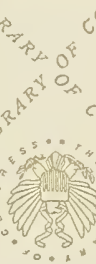

(1)

sulis

(3)

2ins

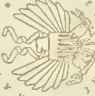

ost $=$

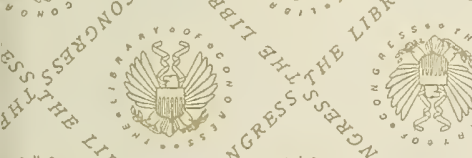

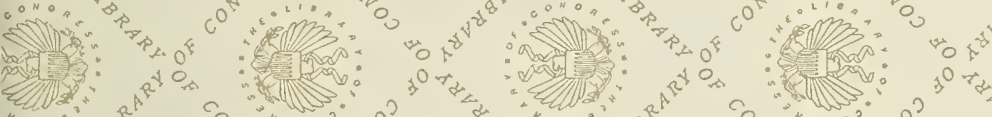

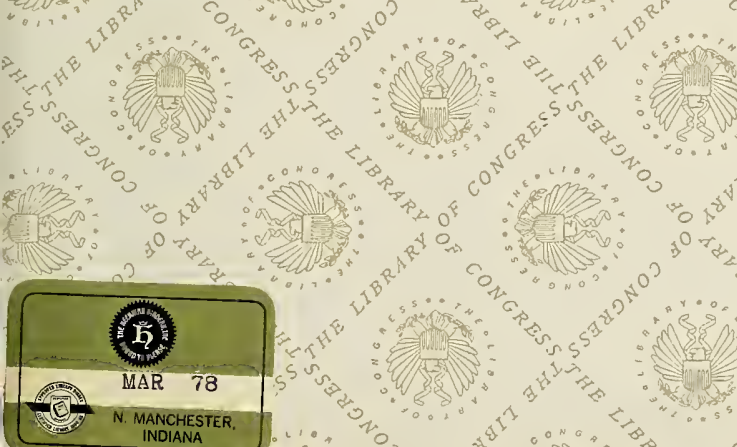


